\title{
Short-term effects of menthol on walking dyspnoea in patients with COPD: a randomised, single blinded, cross-over study
}

\begin{tabular}{|c|c|}
\hline \multirow[b]{2}{*}{$\begin{array}{l}\text { Copyright @The authors } 2021 \\
\text { This version is distributed under } \\
\text { the terms of the Creative } \\
\text { Commons Attribution } \\
\text { Non-Commercial Licence 4.0. } \\
\text { For commercial reproduction } \\
\text { rights and permissions contact } \\
\text { permissions@ersnet.org }\end{array}$} & To the Editor: \\
\hline & $\begin{array}{l}\text { Exertional respiratory discomfort is the most common symptom in patients with COPD [1]. Menthol has } \\
\text { recently been proposed as an ergogenic aid to decrease the perception of dyspnoea during exercise [2-4]. } \\
\text { Menthol activates the transient receptor potential melastatin } 8 \text { (TRPM8) channels in the sensory nerve } \\
\text { fibres of the tongue, promoting a feeling of freshness and a cognitive illusion of airflow into the airways } \\
{[2,5,6] \text {. We hypothesised that chewing menthol-flavoured gum before exercise would decrease the }} \\
\text { perception of dyspnoea during walking in COPD patients. }\end{array}$ \\
\hline \multirow[t]{3}{*}{$\begin{array}{l}\text { Received: } 6 \text { July } 2021 \\
\text { Accepted: } 19 \text { Aug } 2021\end{array}$} & $\begin{array}{l}\text { We conducted a randomised, cross-over, multicentre trial (Groupe Hospitalier du Havre, center hospitalier } \\
\text { de Morlaix, center Resp'Air Talence) (ClinicalTrials.gov identifier: NCT03626519). Inclusion criteria were } \\
\text { diagnosis of COPD (per Global Initiative for Chronic Obstructive Lung Disease guidelines), participation in } \\
\text { a pulmonary rehabilitation programme, functional dyspnoea (modified Medical Research Council (mMRC) } \\
\text { scale } \geqslant 2 \text { ) and consent to participate. Exclusion criteria were clinical instability (pH }<7.35 \text { or body } \\
\text { temperature }>38^{\circ} \mathrm{C} \text { ), neurological/orthopaedic disorders, difficulty with chewing and swallowing disorders. }\end{array}$ \\
\hline & $\begin{array}{l}\text { The primary outcome was end-of-task dyspnoea measured using the modified } 0-10 \text { Borg scale }(0=\text { no } \\
\text { dyspnoea, } 10=\text { maximal dyspnoea). }\end{array}$ \\
\hline & $\begin{array}{l}\text { Secondary outcomes were end-of-task leg discomfort ( } 0-10 \text { Borg scale), peripheral oxygen saturation, } \\
\text { heart rate, tidal volume, minute ventilation, inspiratory capacity and respiratory rate (measured using } \\
\text { Spirodoc (Medical International Research, Rome, Italy)), and 6-min walking distance. After completion of } \\
\text { both tests, participants were asked which condition they had preferred and if they felt that the menthol had } \\
\text { had any effect. }\end{array}$ \\
\hline $\begin{array}{l}\text { W) } \\
\text { Check for } \\
\text { updates }\end{array}$ & $\begin{array}{l}\text { Shareable abstract (@ERSpublications) } \\
\text { Chewing menthol gum prior to exercise is a safe, easy-to-implement, low-cost, non-pharmacologic } \\
\text { intervention that provides a reduction in dyspnoea in a third of patients and decreases the } \\
\text { perception of discomfort during exercise in two-thirds of patients https://bit.ly/3FoFHp1 }\end{array}$ \\
\hline & $\begin{array}{l}\text { Cite this article as: Prieur G, Beaumont M, Delorme M, et al. Short-term effects of menthol on walking } \\
\text { dyspnoea in patients with COPD: a randomised, single blinded, cross-over study. ERJ Open Res 2021; } 7 \text { : } \\
00450-2021 \text { [DOI: } 10.1183 / 23120541.00450-2021] \text {. }\end{array}$ \\
\hline
\end{tabular}


Mean differences were calculated using a mixed model adjusted for baseline values, and the sequence (order of conditions) was used to assess the carry-over effect, with participants as random effects. R-software was used (https://www.R-project.org/) with the packages lme4 and lmerTest [8-10]). Statistical analysis was performed blind.

This study was approved by the French Ethics committee Sud-Est 6 (17 May 2018). Written informed consent was obtained from all patients.

63 patients were included between October 2019 and February 2021 (male/female ratio: 38/25, mean \pm SD age: $68 \pm 20$ years and mean \pm SD body mass index: $27 \pm 7 \mathrm{~kg} \cdot \mathrm{m}^{-2}$ ). Patients had severe bronchial obstruction (mean \pm sD forced expiratory volume in $1 \mathrm{~s}\left(\mathrm{FEV}_{1}\right): 44 \pm 15 \%$ predicted; mean $\pm \mathrm{sD}$ forced vital capacity: $76 \pm 18 \%$ predicted) and lung hyperinflation (mean \pm SD residual volume: $166 \pm 50 \%$ predicted; mean \pm SD total lung capacity: $110 \pm 19 \%$ predicted; mean \pm SD inspiratory capacity: $77 \pm 23 \%$ predicted). All participants had functional dyspnoea (mean \pm SD mMRC 2.4 \pm 0.6 ) and their COPD significantly impacted on their performance of activities of daily living (St George's Respiratory Questionnaire - activities limitations mean \pm SD $68 \pm 20 \%$; scores range from 0 to 100 , higher scores indicate more severe limitations).

A trend towards reduced dyspnoea with menthol was observed, but the benefits were trivial (table 1). The lower bound of the confidence interval did not reach the minimal clinically important difference of 1 point on the modified Borg scale [11]. However, analysis of individual data showed that the menthol reduced dyspnoea by at least 1 point in 21 participants (33\%). 40 participants (63\%) reported a positive effect of the menthol on their exercise tolerance. Only two participants reported having worse dyspnoea in the menthol condition. No between condition differences were observed for the secondary outcomes (table 1). For leg discomfort, there was evidence of a period or cross-over effect $(p=0.050)$, this result should therefore be interpreted with caution. There was no evidence of a period or carry-over effect for any of the other outcomes. No baseline characteristic identified responder patients; however, the confidence interval showed a trend that patients with $\mathrm{FEV}_{1}<35 \%$ predicted were more likely to respond (relative risk 1.67 (95\% CI 0.87-3.21) $\mathrm{p}=0.16)$.

Cooling sensations have previously been shown to reduce dyspnoea. For example, breathing fresh air $\left(7^{\circ} \mathrm{C}\right)$ modestly decreased dyspnoea and increased peak exercise performance in patients with COPD [12]. Menthol can provide a cooling sensation by stimulating the membrane bound ion channel, TRPM8, inducing a perceived reduction in temperature within the range of $8-28^{\circ} \mathrm{C}$ [4]. This cooling sensation could increase the cognitive inspiratory flow and may alter the emotional and affective perception of dyspnoea [2].

TABLE 1 Effects of menthol gum versus control gum on dyspnoea and physiological variables at the end of exercise

\begin{tabular}{|c|c|c|c|c|c|c|}
\hline \multirow[t]{2}{*}{ Variables } & \multicolumn{2}{|c|}{ Menthol } & \multicolumn{2}{|c|}{ Control } & \multicolumn{2}{|l|}{ Condition effect } \\
\hline & Baseline & End-exercise & Baseline & End-exercise & Adjusted mean difference ${ }^{\#}$ & p-value \\
\hline Dyspnoea, mBorg & $0.9 \pm 1$ & $4.4 \pm 1.6^{\star \star \star}$ & $1 \pm 1.0$ & $4.7 \pm 1.7^{\star \star \star}$ & $-0.3(-0.5--0.0)$ & 0.058 \\
\hline Leg discomfort, mBorg & $0.6 \pm 1.1$ & $2.8 \pm 2.1^{\star \star \star}$ & $0.6 \pm 1$ & $2.9 \pm 2.3^{\star \star \star}$ & $-0.0(-0.3-0.2)$ & 0.807 \\
\hline$S_{\mathrm{pO}_{2}}, \%$ & $92.6 \pm 3.7$ & $85.7 \pm 7^{\star \star \star}$ & $92.6 \pm 3.3$ & $86.3 \pm 6.2^{\star \star \star}$ & $-0.4(-1.0-0.3)$ & 0.255 \\
\hline Lowest $S_{\mathrm{pO}_{2}}, \%$ & & $82.7 \pm 7.3$ & & $83.1 \pm 6.6$ & $-0.4(-1.2-0.3)$ & 0.263 \\
\hline Heart rate, beats per min & $91.4 \pm 17.8$ & $115.3 \pm 15.2^{\star \star \star}$ & $92.3 \pm 17.5$ & $114.5 .9 \pm 15.7^{\star \star \star}$ & $4.4(-1.2-9.9)$ & 0.124 \\
\hline Respiratory rate, cycles per min & $18.6 \pm 4.6$ & $24.1 \pm 9.5^{\star \star \star}$ & $19 \pm 5.2$ & $24.1 \pm 5.9 \star \star \star$ & $0.3(-2.1-2.6)$ & 0.827 \\
\hline Tidal volume, $\mathrm{L}$ & $0.8 \pm 0.3$ & $1.1 \pm 0.5^{\star \star \star}$ & $0.8 \pm 0.4$ & $1.1 \pm 0.5^{\star \star \star}$ & $0.0(-0.0-0.1)$ & 0.172 \\
\hline Minute ventilation, $\mathrm{L} \cdot \mathrm{min}^{-1}$ & $13.9 \pm 5.1$ & $25.6 \pm 9.3^{\star \star \star}$ & $14.7 \pm 5.6$ & $25.8 \pm 9^{\star \star \star}$ & $-0.1(-1.5-1.3)$ & 0.924 \\
\hline Inspiratory capacity, L & $1.8 \pm 0.6$ & $1.7 \pm 0.6^{\star \star}$ & $1.9 \pm 0.7$ & $1.8 \pm 0.7$ & $-0.0(-0.2-0.1)$ & 0.449 \\
\hline 6MWD, m & & $461.1 \pm 124.2$ & & $458.7 \pm 124.9$ & $2.6(-4.1-9.4)$ & 0.447 \\
\hline 6MWD, \% pred & & $73.1 \pm 20.7$ & & $72.8 \pm 20.7$ & $0.37(-0.76-1.5)$ & 0.495 \\
\hline
\end{tabular}

Continuous data are presented as mean \pm SD and as mean $(95 \% \mathrm{Cl})$ for the difference between the two conditions. Mean differences were calculated using a mixed model adjusted for baseline values, and the sequence (order of conditions) was used to assess the carry-over effect, with participants as random effects. Within-condition changes (before-after test) were compared using a paired $t$-test. ${ }^{\star}: p<0.05$; ${ }^{\star \star}: p<0.01 ;$ and ${ }^{* \star *}: p<0.001$ for before-after analysis of a condition. mBorg: modified Borg scale from 0 to 10 ( 0 : no fatigue or dyspnoea, 10: maximal fatigue or dyspnoea). For leg discomfort, there was evidence for a period or cross-over effect $(p=0.050)$, this result should be taken with caution. There was no evidence of a period or cross-over effect on the other outcomes. $S_{\mathrm{pO}_{2}}$ : oxygen saturation measured by pulse oximetry; 6MWD: 6-min walking distance. " : difference for menthol - control. 
The results of the present study showed a clinically trivial effect of menthol on end-test dyspnoea compared with the control condition; however, the reduction in dyspnoea reached the minimal clinically important difference in one-third of the participants and two-thirds reported a positive effect on their exercise tolerance.

We propose two explanations for this small effect. First, the Borg scale may not be sufficiently sensitive to detect a between-condition difference. The study by KANEZAKI et al. [2] found a reduction in physical and mental breathing effort, air hunger, breathing discomfort, anxiety, and fear during inspiratory resistive loaded breathing in patients with COPD following olfactive stimulation by L-menthol using the Multidimensional Dyspnea Profile scale. This reflects the self-reported perception of the patients in our study. Secondly, individuals often modify their level of exertion during self-paced exercise tests, based on their level of dyspnoea. This could also explain why other studies failed to show a benefit of non-pharmacological strategies on exertional dyspnoea using the 6MWT [13, 14]. High-intensity constant work rate endurance tests are more sensitive for the detection of the effectiveness of an intervention $[3,15,16]$.

Although no carry-over effect of menthol was observed on dyspnoea, we do not know the duration of the effect of menthol and its potential impact on the next condition is not known. Future studies could perhaps include a washout period longer than 30 min between the two conditions.

Another explanation for the negative result is that the sensation of breathing comfort faded over the course of the test as the menthol effect dissipated: several participants reported that they mainly felt the benefit during the first few minutes of the test. Studies in athletes reported a stronger effect of repeated menthol use on dyspnoea and on performance [4]. The lack of an effect on ventilatory pattern is in line with the results of KANEZAKI et al. [2].

This study addressed a new area of research, looking at alternative and pragmatic approaches to the management of breathlessness. Future studies should take the methodological limitations that we outlined into consideration to optimise future studies in this field.

This multicentre study has several strengths: the assessors were blinded to limit measurement bias and the instructions given to patients were standardised to limit a centre effect. Patients were unaware that the primary outcome was dyspnoea to minimise the influence on this outcome. We asked patients to be as honest as possible about how they felt about menthol, and to report both positive and negative aspects.

Chewing menthol gum prior to exercise is a safe, easy-to-implement, low-cost, non-pharmacological intervention that provides a clinically important reduction in dyspnoea in one third of patients and decreases the perception of discomfort during exercise in two-thirds of patients. Continuous release or repeated administration of menthol may have a greater effect on dyspnoea reduction throughout exercise [4].

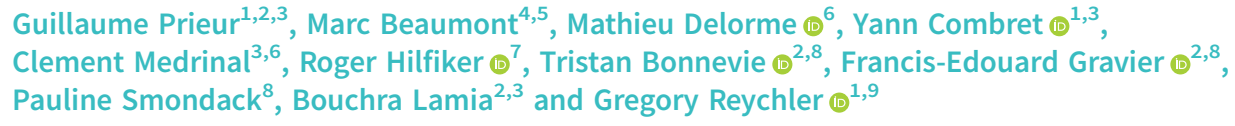

${ }^{1}$ Institut de Recherche Expérimentale et Clinique (IREC), Pôle de Pneumologie, ORL and Dermatologie, Groupe de Recherche en Kinésithérapie Respiratoire, Université Catholique de Louvain, Brussels, Belgium. ${ }^{2}$ Normandie Univ, UNIROUEN, EA3830-GRHV, Institute for Research and Innovation in Biomedicine (IRIB), Rouen, France. ${ }^{3}$ Groupe Hospitalier du Havre, Pulmonology Dept and Pulmonary Rehabilitation Dept, Montivilliers, France. ${ }^{4}$ Pulmonary Rehabilitation Dept, CH des Pays de Morlaix, Kersaint Gilly, Morlaix, France. ${ }^{5}$ EA3878 (GETBO) CIC INSERM 1412, European University of Occidental Brittany, Brest, France. ${ }^{6}$ Université Paris-Saclay, UVSQ, ERPHAN, Versailles, France. ${ }^{7}$ University of Applied Sciences and Arts Western Switzerland Valais (HES-SO Valais-Wallis), Physiotherapy, Sierre, Switzerland. ${ }^{8}$ ADIR Association, Rouen University Hospital, Rouen, France. ${ }^{9}$ Service de Pneumologie, Cliniques Universitaires Saint-Luc, Brussels, Belgium.

Corresponding author: Guillaume Prieur (gprieur.kine@gmail.com) 
Provenance: Submitted article, peer reviewed.

This study is registered at www.ClinicalTrials.gov with identifier number NCT03626519. All of the anonymised individual participant data collected during the trial are available (no end date). Requests should be directed to gprieur.kine@gmail.com.

Conflict of interest: None declared.

Support statement: This work was supported by GHAHR Association (Le Havre, France).

\section{References}

1 Nishimura K, Izumi T, Tsukino M, et al. Dyspnea is a better predictor of 5-year survival than airway obstruction in patients with COPD. Chest 2002; 121: 1434-1440.

2 Kanezaki M, Terada K, Ebihara S. Effect of olfactory stimulation by L-menthol on laboratory-induced dyspnea in COPD. Chest 2020; 157: 1455-1465.

3 Kanezaki M, Ebihara S. Effect of the cooling sensation induced by olfactory stimulation by L-menthol on dyspnoea: a pilot study. Eur Respir J 2017; 49: 1601823.

4 Barwood MJ, Gibson OR, Gillis DJ, et al. Menthol as an ergogenic aid for the Tokyo 2021 Olympic Games: an expert-led consensus statement using the modified Delphi method. Sports Med 2020; 50: 1709-1727.

5 Peier AM, Moqrich A, Hergarden AC, et al. A TRP channel that senses cold stimuli and menthol. Cell 2002; 108: 705-715.

6 McKemy DD, Neuhausser WM, Julius D. Identification of a cold receptor reveals a general role for TRP channels in thermosensation. Nature 2002; 416: 52-58.

7 Ries AL. Minimally clinically important difference for the UCSD shortness of breath questionnaire, Borg scale, and visual analog scale. COPD: J Chron Obstruct Pulmon Dis 2005; 2: 105-110.

8 Senn S. Cross-over Trials in Clinical Research. 2nd Edn. New York, J. Wiley, 2002.

9 Bates D, Mächler M, Bolker B, et al. Fitting linear mixed-effects models using Ime4. J Stat Soft 2015; 67: 1-48.

10 Kuznetsova A, Brockhoff PB, Christensen RHB. ImerTest package: tests in linear mixed effects models. J Stat Soft 2017; 82: 1-26.

11 Jones PW, Beeh KM, Chapman KR, et al. Minimal clinically important differences in pharmacological trials. Am J Respir Crit Care Med 2014; 189: 250-255.

12 Spence DPS, Graham DR, Ahmed J, et al. Does cold air affect exercise capacity and dyspnea in stable chronic obstructive pulmonary disease? Chest 1993; 103: 693-696.

13 Pfister T, Berrol C, Caplan C. Effects of music on exercise and perceived symptoms in patients with chronic obstructive pulmonary disease. J Cardiopulm Rehabil 1998; 18: 228-232.

14 Caty G, Pieters T, Liistro G, et al. Influence of music with a fast tempo on the 6-minute walk test in copd patients. Ann Phys Rehabil Med 2013; 56: e327.

15 Lee AL, Dolmage TE, Rhim M, et al. The impact of listening to music during a high-intensity exercise endurance test in people with COPD. Chest 2018; 153: 1134-1141.

16 Borel B, Provencher S, Saey D, et al. Responsiveness of various exercise-testing protocols to therapeutic interventions in COPD. Pulm Med 2013; 2013: 410748. 